\title{
RBC Transfusion Triggers: Is There Anything New?
}

\author{
Tina Tomic Mahecic ${ }^{\mathrm{a}} \quad$ Martin Dünser $^{\mathrm{b}} \quad$ Jens Meier $^{\mathrm{b}}$ \\ ${ }^{a}$ Department of Anesthesiology and Intensive Care Medicine, University Hospital Center Zagreb - Rebro, \\ Zagreb, Croatia; ${ }^{b}$ Department of Anesthesiology and Intensive Care Medicine, Johannes Kepler University, \\ Linz, Austria
}

\section{Keywords}

Transfusion threshold - Anemia tolerance - Limits of anemia . Physiological transfusion trigger

\begin{abstract}
For many years, in daily clinical practice, the traditional $10 / 30$ rule (hemoglobin $10 \mathrm{~g} / \mathrm{dL}$ - hematocrit 30\%) has been the most commonly used trigger for blood transfusions. Over the years, this approach is believed to have contributed to a countless number of unnecessary transfusions and an unknown number of overtransfusion-related deaths. Recent studies have shown that lower hemoglobin levels can safely be accepted, even in critically ill patients. However, even these new transfusion thresholds are far beyond the theoretical limits of individual anemia tolerance. For this reason, almost all publications addressing the limits of acute anemia recommend physiological transfusion triggers to indicate the transfusion of erythrocyte concentrates as an alternative. Although this concept appears intuitive at first glance, no solid scientific evidence supports the safety and benefit of physiological transfusion triggers to indicate the optimal time point for transfusion of allogeneic blood. It is therefore imperative to continue searching for the most sensitive and specific parameters that can guide the clinician when to transfuse in order to avoid anemia-induced organ dysfunction while avoiding overtransfusion-related adverse effects. This narrative review discusses the concept of anemia tolerance and critically compares hemoglobin-based triggers with physiological transfusion for various clinical indications.

(c) 2020 S. Karger AG, Basel
\end{abstract}

\section{Introduction}

During the last few years, "patient blood management" has emerged as an integral part of patient care, particularly in surgery [1]. This bundle of different measures aims at improving patient outcomes by combining three "treatment pillars," of which one is to utilize anemia tolerance of a specific patient in a rational way [2]. From a historical perspective, anemia tolerance has been investigated especially in situations where the transfusion of red blood cells (RBCs) was impossible or declined. The most famous examples for the latter situation are Jehovah's Witnesses who decline the transfusion of RBCs for religious beliefs. It has been shown in these patients that anemia tolerance is much lower than generally anticipated, and therefore transfusion above hemoglobin $(\mathrm{Hb})$ values of $8 \mathrm{~g} / \mathrm{dL}$ might be needless [3]. The first to demonstrate this in a general intensive-care unit population were Hébert et al. [4], who initiated a large amount of studies that investigate a liberal versus a more restrictive transfusion regime. Since then, a plethora of studies have demonstrated that avoiding premature transfusion results in a substantial reduction of overall $\mathrm{RBC}$ usage without compromising organ function or survival $[5,6]$. However, what sounds very appealing and logical at first glance is very difficult to achieve in clinical practice. Depending on the situation, it is a challenge to differentiate between "premature" and "adequate" transfusion and determine the individual limits of anemia tolerance. This uncertainty about the optimal transfusion threshold becomes even more pronounced as the bulk of the classical literature 
highlights that moderate and even mild anemia is a significant perioperative risk factor implicating that it might be advisable to avoid any degree of anemia in surgical patients as far as possible [7-10]. However, it cannot be concluded from these data that the restoration of normal $\mathrm{Hb}$ levels by transfusing RBCs reverses any anemia-related increase in mortality.

An optimal transfusion trigger should (1) avoid delayed transfusion, (2) avoid premature transfusion, (3) take into account the different degrees of anemia tolerance of different organs, (4) be determined continuously, and (5) have a high sensitivity and specificity.

For years, one way to guide the physician's decision for or against transfusion was the use of the $\mathrm{Hb}$ concentration or the hematocrit [11]. The physiological rationale for this approach is that both $\mathrm{Hb}$ and hematocrit are key determinants of arterial oxygen delivery $\left(\mathrm{DO}_{2}\right)$ and therefore the lower limit of oxygen transport and adequate tissue oxygenation. However, this approach neglects the fact that oxygen transport capacity and thus tissue oxygenation are critically influenced by compensatory mechanisms of the cardiovascular system and the microcirculation.

Despite these shortcomings, a huge amount of literature has been published on the effects of a liberal versus restrictive transfusion regimen (i.e., higher or lower $\mathrm{Hb}$ as transfusion threshold) on outcome [12]. The results of these trials formed the majority of the current scientific evidence and informed most guidelines on RBC transfusion [13]. As a consequence, most of these guidelines primarily focus on an $\mathrm{Hb}$-based transfusion trigger, and only some of them essentially integrate the concept of physiological transfusion triggers to find the optimal time point for transfusion [14].

This narrative review summarizes the physiological basis for an $\mathrm{Hb}$ - or hematocrit-based transfusion regimen compared to physiological transfusion triggers and critically discusses the current literature. Furthermore, it suggests a research agenda that might help to enable the scientific community to enlighten the concept of transfusion triggers with the aim to increase both efficacy and safety of blood transfusions.

\section{The Physiological Rationale of Hb-Based Transfusion Triggers}

The human organism depends on a certain amount of oxygen for adequate metabolism in different situations (so-called oxygen demand). Oxygen demand can range from $2.9 \pm 0.4 \mathrm{~mL} / \mathrm{kg} / \mathrm{min}$ for resting elderly women, to $>50 \mathrm{~mL} / \mathrm{kg} / \mathrm{min}$ in sporting, young men, and close to 100 $\mathrm{mL} / \mathrm{min} / \mathrm{kg}$ among professional athletes at maximum performance [15]. Accordingly, the respiratory and car- diovascular systems need physiological mechanisms to adjust $\mathrm{DO}_{2}$ to a broad range of oxygen demands under different situations in daily life. $\mathrm{DO}_{2}$ is mainly determined by three factors: cardiac output $(\mathrm{CO}), \mathrm{Hb}$ and $\mathrm{Hb}$ oxygenation.

$$
\mathrm{DO}_{2}=\left(\mathrm{Hb} \times 1.34 \times \mathrm{SaO}_{2}+0.0031 \times \mathrm{PaO}_{2}\right) \times \mathrm{CO},
$$

where $\mathrm{SaO}_{2}$ is arterial oxygen saturation and $\mathrm{PaO}_{2}$ arterial partial pressure of oxygen. Even under resting conditions, $\mathrm{DO}_{2}$ exceeds oxygen demand by about 4 -fold [16]. The need to adapt to different conditions is the reason why $\mathrm{CO}$ can be varied over a wide range and $\mathrm{Hb}$ is usually higher than what is necessary for survival.

A restriction in any of these factors reduces the organism's capacity to increase $\mathrm{DO}_{2}$ in response to higher $\mathrm{O}_{2}$ demand. In clinical practice, it is assumed that there is a lower limit of $\mathrm{DO}_{2}$ below which oxygen supply does no longer meet tissue oxygen demand resulting in tissue hypoxia even under resting conditions. Animal models suggest that this critical $\mathrm{DO}_{2}$ limit is approximately $9-11 \mathrm{~mL} /$ $\mathrm{kg} / \mathrm{min}$ for anemia, hypoxia, or low cardiac output [1719]. But even at higher $\mathrm{Hb}$ values, and by that higher $\mathrm{DO}_{2}$ thresholds, acute anemia seems to influence survival. Tobian et al. [20] demonstrated that the survival time of Jehovah's Witnesses dying with acute anemia essentially depends on the $\mathrm{Hb}$ value, giving the physician a window of opportunity to intervene depending on the actual $\mathrm{Hb}$ value. These results clearly demonstrate that not only a $\mathrm{DO}_{2}$ close to or below $10 \mathrm{~mL} / \mathrm{kg} / \mathrm{min}$ should be avoided, but that even higher thresholds might be dangerous, probably due to additional mechanisms. In 293 patients, the odds of death are increasing 2.04 times for each $1.0 \mathrm{~g} /$ $\mathrm{dL}$ decrease in nadir $\mathrm{Hb}$ [21]. Although the critical $\mathrm{DO}_{2}$ is used as a general concept for determining anemia tolerance, it is unlikely that a clear limit can be drawn from these values. Any long-term effects could be missed by this approach.

Furthermore, these values are only a rough guess and cannot be applied generally in daily clinical practice. First of all it has to be pointed out that anemia tolerance of different organs can vary [22], and second there might be several clinical situations like vascular stenosis, sepsis, application of $\beta$-blockers, etc., where these simple physiological considerations cannot be applied easily [23]. However, Carson et al. [24] investigated a liberal versus a restrictive transfusion regime in cordially compromised patients and could not find any difference in the 60-day mortality or the ability to walk.

Furthermore, in clinical practice, this lower $\mathrm{DO}_{2}$ limit is rarely reached by anemia alone. In most of the typical clinical scenarios, a combination of anemia and hypovolemia with or without hypoxemia reduces $\mathrm{DO}_{2}$. Usually, patients are transfused at an $\mathrm{Hb} \geq 7 \mathrm{~g} / \mathrm{dL}$, a value that ensures $\mathrm{DO}_{2}$ to be far above the limit mentioned above. Ac- 
Table 1. Effects of a restrictive versus liberal transfusion policy

\begin{tabular}{|c|c|c|}
\hline Study & Population & Main outcome \\
\hline Hébert et al. [4], 1999 & $\begin{array}{l}838 \text { surgical and nonsurgical ICU } \\
\text { patients with restrictive vs. liberal } \\
\text { transfusion }\end{array}$ & 30-day mortality was similar in the restrictive and in the liberal group \\
\hline Hajjar et al. [25], 2010 & $\begin{array}{l}502 \text { postcardiac surgery patients with } \\
\text { restrictive vs. liberal transfusion }\end{array}$ & $\begin{array}{l}\text { The composite end point of } 30 \text {-day all-cause mortality and severe morbidity } \\
\text { (cardiogenic shock, acute respiratory distress syndrome, or acute renal injury } \\
\text { requiring dialysis or hemofiltration) was similar between both groups }\end{array}$ \\
\hline Carson et al. [24], 2011 & $\begin{array}{l}2,016 \text { cardiovascular high-risk patients } \\
\text { undergoing total hip or total knee } \\
\text { replacement }\end{array}$ & $\begin{array}{l}\text { Patients in the liberal group were transfused more often, whereas the primary } \\
\text { outcome (death or an inability to walk across a room without human } \\
\text { assistance on } 60 \text {-day follow-up) was similar in both groups }\end{array}$ \\
\hline Villanueva et al. [59], 2012 & $\begin{array}{l}921 \text { patients with severe acute upper } \\
\text { gastrointestinal bleeding }\end{array}$ & $\begin{array}{l}\text { Probability of survival at } 6 \text { weeks was higher in the restrictive-strategy group } \\
\text { than in the liberal-strategy group }\end{array}$ \\
\hline Holst et al. [27], 2014 & 998 patients with septic shock & $\begin{array}{l}\text { Whereas the liberal group received } 4 \text { times as many transfusions as the } \\
\text { restrictive group, mortality was similar in both groups }\end{array}$ \\
\hline Bergamin et al. [60], 2017 & $\begin{array}{l}300 \text { adult cancer patients with septic } \\
\text { shock in the first } 6 \text { h of ICU admission }\end{array}$ & $\begin{array}{l}\text { Patients in the liberal group received more RBC units than patients in the } \\
\text { restrictive group. At } 28 \text { days after randomization, mortality rate in the liberal } \\
\text { group was similar to mortality in the liberal group with no differences in ICU } \\
\text { and hospital length of stay. This comparison was in favor of the liberal group } \\
\text { at day } 90\end{array}$ \\
\hline Mazer et al. [26], 2017 & $\begin{array}{l}5,243 \text { adults undergoing cardiac surgery } \\
\text { who had a EuroSCORE I of } 6 \text { or more }\end{array}$ & $\begin{array}{l}\text { The primary outcome (death from any cause, myocardial infarction, stroke, } \\
\text { or new-onset renal failure with dialysis by hospital discharge or by day } 28 \text {, } \\
\text { whichever came first) occurred similarly often in the restrictive-threshold } \\
\text { group, as well as in the liberal-threshold group }\end{array}$ \\
\hline
\end{tabular}

ICU, intensive-care unit; RBC, red blood cell; EuroSCORE, European System for Cardiac Operative Risk Evaluation.

cordingly, in current practice, RBCs are not transfused at the physiological limits of anemia but clearly before that threshold. Consequently, Hb-based transfusion thresholds cannot be explained by physiological $\mathrm{DO}_{2}$ limits alone but are rather a result of a need for security. In daily clinical practice, it is believed that there exists a hierarchy of all transfusion triggers (Fig. 1). However, whether this holds true in daily clinical practice remains open for discussion.

\section{What Is the Rationale for Current Hb-Based Transfusion Recommendations?}

Nearly all current transfusion guidelines recommend that RBCs should not be transfused at an $\mathrm{Hb} \geq 10 \mathrm{~g} / \mathrm{dL}$ (with the potential exception of univentricular pediatric cardiac surgery), while RBC transfusion is nearly always recommended at an $\mathrm{Hb}<6 \mathrm{~g} / \mathrm{dL}[11,13,14]$. Therefore, individual transfusion triggers vary between an $\mathrm{Hb}$ of 6 and $10 \mathrm{~g} / \mathrm{dL}$ and are mostly determined by taking the patient's medical condition and comorbidities into account. Most guidelines recommend applying an $\mathrm{Hb}$ threshold of $7 \mathrm{~g} / \mathrm{dL}$ in relatively "healthy" patients, whereas patients with cardiovascular compromise should be transfused at an $\mathrm{Hb}$ of $8 \mathrm{~g} / \mathrm{dL}$ [11].

Although these thresholds are far above the physiological limits of acute anemia, they are based on the results of several clinical studies comparing the outcome effects

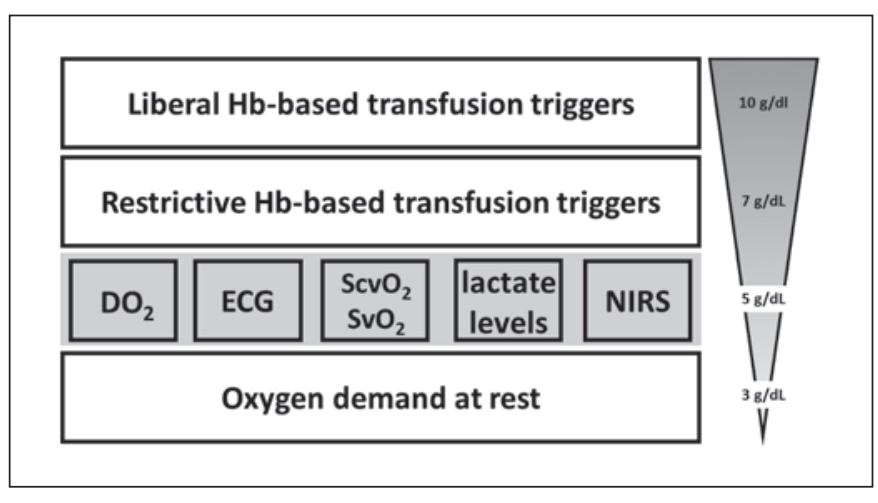

Fig. 1. Hypothetical hierarchy of transfusion triggers. Physiological transfusion triggers are shaded in gray highlighting their low sensitivity and specificity to predict the need for RBC transfusion. $\mathrm{DO}_{2}$, systemic oxygen delivery; ECG, electrocardiogram; NIRS, near-infrared spectroscopy; $\mathrm{ScvO}_{2}$, central venous oxygen saturation; $\mathrm{SvO}_{2}$, mixed venous oxygen saturation.

of a restrictive transfusion regimen (defined by a transfusion threshold near 7-8 g/dL) to a liberal one (defined by a transfusion threshold of $9 \mathrm{~g} / \mathrm{dL}$ ) [4, 24-27]. While studies performed in the 1990s compared the two regimes retrospectively mostly in critically ill patients $[28,29]$, randomized controlled trials published during the following years evaluated the effects of a restrictive versus liberal transfusion policy also in several other patient populations (Table 1). 
Table 2. Advantages and disadvantages of various transfusion triggers

\begin{tabular}{lll}
\hline Transfusion trigger & Advantages & Disadvantages \\
\hline $\mathrm{Hb} /$ Hct based & $\begin{array}{l}\text { Hb or Hct are easy to measure } \\
\text { Clear cutoff values } \\
\text { No physiological considerations needed }\end{array}$ & $\begin{array}{l}\text { Hb and Hct are only surrogate parameters of oxygen transport } \\
\text { Despite huge efforts cutoff values are poorly defined } \\
\text { Typical thresholds are rather high }\end{array}$ \\
\hline $\mathrm{DO}_{2}$ & $\begin{array}{l}\mathrm{DO}_{2} \text { describes oxygen delivery to the whole } \\
\text { body } \\
\text { It is the key figure for adequate tissue oxygen } \\
\text { delivery }\end{array}$ & $\begin{array}{l}\mathrm{DO}_{2} \text { is rarely calculated as it is difficult to determine, requires measurement } \\
\text { of cardiac output and blood gas analysis } \\
\text { Only whole-body oxygen delivery is described. Organ-specific restrictions are } \\
\text { neglected }\end{array}$ \\
& $\begin{array}{l}\text { Some pathologies might influence tissue oxygenation despite adequate DO } \\
\text { (e.g., vascular stenoses, etc.) }\end{array}$ \\
\hline ECG & Easily applicable and widely available & $\begin{array}{l}\text { Very low sensitivity } \\
\text { Poorly investigated in the setting of acute anemia } \\
\text { S-T segment changes are rather late signs of myocardial hypoxia }\end{array}$ \\
\hline SvO ${ }_{2}, \mathrm{ScO}_{2}$ & $\begin{array}{l}\text { Broadly used to determine adequate tissue } \\
\text { oxygenation }\end{array}$ & $\begin{array}{l}\text { A decline in both parameters is part of the compensatory mechanisms of } \\
\text { acute anemia } \\
\text { Also influenced by other factors such as cardiac output, arterial oxygen } \\
\text { saturation, tissue metabolism, etc. }\end{array}$ \\
\hline Arterial lactate levels & Good indicator of tissue hypoxia & $\begin{array}{l}\text { Neither sensitive nor specific for tissue hypoxia } \\
\text { Arterial lactate levels only rise with some delay in acute anemia }\end{array}$ \\
\hline NIRS & $\begin{array}{l}\text { Allows for organ-specific measurement of } \\
\text { tissue hypoxia }\end{array}$ & $\begin{array}{l}\text { Not yet sufficiently validated in acute anemia } \\
\text { Organ-specific anemia }\end{array}$ \\
$\begin{array}{l}\text { Comprehensive theoretical concept for } \\
\text { upcoming transfusion triggers }\end{array}$ & $\begin{array}{l}\text { No standardized measurement of regional tissue hypoxia has yet been } \\
\text { defined }\end{array}$ \\
\hline
\end{tabular}

$\mathrm{Hb}$, hemoglobin; Hct, hematocrit; $\mathrm{DO}_{2}$, arterial oxygen delivery; ECG, electrocardiogram; $\mathrm{SvO}_{2}$, central/mixed venous oxygen saturation; $\mathrm{ScO}{ }_{2}$, central oxygen saturation; NIRS, near-infrared spectroscopy.

As no common definition of "liberal" and "restrictive" transfusion thresholds has been agreed on, relevant heterogeneities in $\mathrm{Hb}$ levels used as transfusion triggers exist among these trials [12]. Accordingly, what was considered a liberal transfusion threshold in one study was used as a restrictive trigger in another trial [30]. Furthermore, as pointed out above, none of these studies is truly "restrictive" from a physiological point of view. Accordingly, a "restrictive" versus "liberal" transfusion regimen might well be referred to as a "liberal" versus an "even more liberal" transfusion policy. Nonetheless, the results of these trials proved that a lower $\mathrm{Hb}$ limit of $7 \mathrm{~g} / \mathrm{dl}$ is a safe transfusion threshold for most patients with the possible exception of patients with acute myocardial ischemia [31]. However, what we do not know from these studies is whether even lower transfusion thresholds could not be safely applied in specific patient groups. During the last few years, the main focus has been set on the safety of a restrictive regimen for patient groups with cardiac risk factors, but so far no studies have compared a "restrictive" transfusion threshold with even lower Hb levels as transfusion triggers (e.g., $6 \mathrm{~g} / \mathrm{dL}$ ). Knowing that every RBC transfusion is associated with significant risks, it can be hypothesized that using even lower Hb levels as a transfusion trigger could be beneficial at least for some patient groups. The question even arises whether there are more accurate parameters than $\mathrm{Hb}$ to guide transfusion in clinical practice. At least in patients with preserved cardiovascular function, the individual limit of anemia could theoretically be determined using physiological parameters thereby avoiding both premature transfusion and the potential risk of tissue hypoxia.

\section{Are There Other Clinically Useful Transfusion Triggers?}

Nearly all transfusion guidelines recommend using physiological transfusion triggers $[11,13]$. The rationale for this concept is to utilize a physiological parameter which reaches a specific value as soon as the compensatory limits of acute anemia are reached. Potential targets might be $\mathrm{DO}_{2}$, central/mixed venous oxygen saturation $\left(\mathrm{SvO}_{2}\right)$, central venous oxygen saturation $\left(\mathrm{ScvO}_{2}\right)$, lactate levels, any signs of myocardial ischemia, arterial hypotension, or tachycardia (Table 2). Although this idea is appealing, there are several factors limiting the use of these triggers in clinical practice. 


\section{$\mathrm{DO}_{2}$ as a Transfusion Trigger}

From a physiological point of view, $\mathrm{DO}_{2}$ appears to be a useful parameter to indicate the optimal time point of transfusion. If $\mathrm{Hb}$ decreases and $\mathrm{DO}_{2}$ falls below a given threshold, RBC transfusion seems reasonable to avoid tissue hypoxia. Since not all of the oxygen delivered to the tissues is utilized under normal conditions, $\mathrm{DO}_{2}$ is rather a surrogate of utilizable oxygen than a reliable indicator of tissue oxygen extraction [32]. Even in conditions where oxygen demand increases, oxygen extraction from arterial blood is limited in such a way that even at very low $\mathrm{DO}_{2}$ levels venous oxygen saturations rarely drop below $40 \%$ [33]. This indicates that even in situations where tissue oxygenation is endangered, only $60 \%$ of oxygen delivered can be utilized for tissue oxygenation. This implies that an increase in $\mathrm{Hb}$ does not necessarily translate into a higher amount of usable oxygen $[34,35]$.

Furthermore, it is often overseen that $\mathrm{Hb}, \mathrm{SaO}_{2}, \mathrm{PaO}_{2}$, and $\mathrm{CO}$ are interdependent. As a consequence, an increase in one of them might result in a decrease of the other, leaving $\mathrm{DO}_{2}$ unaltered. For example, an increase in $\mathrm{Hb}$ results in a rise of blood viscosity and by that a decrease in CO. This dependency has been analyzed theoretically [36] and verified in theoretical experiments [37]. However, the clinical relevance of this interdependency has not yet been thoroughly investigated. Similarly, changes in $\mathrm{PaO}_{2}$ and by that $\mathrm{SaO}_{2}$ influence $\mathrm{CO}$. High $\mathrm{PaO}_{2}$ values induce the formation of 20 -hydroxyeicosatetraenoic acid and thus mediate potent vasoconstriction which in response increases afterload and decreases $\mathrm{CO}$ leaving $\mathrm{DO}_{2}$ unchanged despite an increase in arterial oxygen content $[32,38,39]$. Taking these interdependencies into account, the use of $\mathrm{DO}_{2}$ as a transfusion trigger appears impracticable, as the effect of any potential intervention is difficult to judge. Finally, the measurement of $\mathrm{DO}_{2}$ in clinical practice is difficult. This is mainly due to the fact that $\mathrm{CO}$ is rarely measured, even in critically ill patients.

\section{The Electrocardiogram as a Transfusion Trigger}

By recording the electrical activity of the myocardium, a 12-channel electrocardiogram (ECG) can detect any myocardial hypoxia in a timely manner. It has repeatedly been shown that severe anemia causes changes of the ECG trace, which can be reversed by RBC transfusion [40]. Accordingly, the ECG has been used to detect myocardial hypoxia in acute anemia [41] and appears to be an interesting technique to determine the individual transfusion trigger, particularly in patients with cardiovascular risk factors. Pappachan et al. [40] were able to demonstrate that changes in the ST segment correlate well with the extent of acute anemia. Despite its simple applicability, no large clinical trial has so far investigated the safety of using ECG changes as a transfusion trigger. In particular, it has not yet been fully clarified whether the occurrence of significant ECG changes is not an indicator of irreversible myocardial damage for some of the clinical situations. For these reasons, the ECG cannot (yet) be recommended to determine the individual transfusion threshold.

\section{$\mathrm{SvO}_{2}$ and $\mathrm{ScvO}_{2}$ as Transfusion Triggers}

As outlined above, most of the oxygen-transporting cycles through the cardiovascular system remain unused. An increase in oxygen demand regularly decreases $\mathrm{SvO}_{2}$, each time when the main compensatory mechanism in this situation is an increase in oxygen extraction in the microcirculation. However, there are also other clinical situations, and by that other mechanisms that can compensate for an increase in oxygen demand (e.g., an increase in $\mathrm{CO}$ ) leaving $\mathrm{SvO}_{2}$ unchanged despite increased tissue oxygen demand. If $\mathrm{DO}_{2}$ is decreased by normovolemic anemia, there is usually a certain time point when $\mathrm{SvO}_{2}$ decreases [42] This time point is often referred to as a potential transfusion threshold as it could indicate that other compensatory mechanisms fail to maintain sufficient oxygen delivery [43]. A study in neurosurgical patients demonstrated that a decrease in $\mathrm{SvO}_{2}<70 \%$ could predict the adequacy of transfusion with an area under the curve of 0.891 . This compared favorably to an $\mathrm{Hb}$ threshold of $7 \mathrm{~g} / \mathrm{dl}$ which exhibited an area under the curve of 0.622 [44].

However, a change in $\mathrm{SvO}_{2}$ is a normal, physiological compensatory mechanism in the course of any changes in oxygen delivery, and therefore a decline of $\mathrm{SvO}_{2}$ does not necessarily indicate that tissue oxygenation is at risk. This holds especially true in situations where tissue oxygen extraction and utilization are impaired, such as in septic shock. In these patients, $\mathrm{SvO}_{2}$ frequently remains high despite tissue hypoxia [45]. Under these conditions, RBC transfusion may even decrease $\mathrm{DO}_{2}$ and could, therefore, be considered potentially harmful. All these considerations also apply for $\mathrm{ScvO}_{2}$ as a potential transfusion trigger, and therefore both methods have similar weaknesses. However, $\mathrm{ScvO}_{2}$ has the additional drawback of reflecting the oxygen balance of the upper part of the body rather than the lower part, which further reduces its usefulness.

\section{Arterial Lactate as a Transfusion Trigger}

From a theoretical point of view, lactate levels appear to be a very reasonable transfusion trigger. If $\mathrm{Hb}$ declines to such a degree that tissue oxygen demand can no longer 
be met, tissue hypoxia occurs resulting in a rise in lactate levels. The lactate concentration can then be determined easily and cost-effectively at the bedside with the aid of a point of care device, which greatly simplifies its use in daily clinical practice. Surprisingly, no study has investigated this concept in moderately bleeding patients. Only in patients with trauma-associated bleeding or sepsis with concomitant anemia, transfusion guidance by measuring lactate levels plays a clinical role [46]. The reason for this is the chronological sequence of the occurrence of pathophysiological changes in the context of acute anemia. While changes in mixed or central venous oxygen saturation occur very early, an increase in lactate levels is a late indicator of acute anemia [47]. Weiskopf et al. [48] found that lactate levels did not increase until Hb levels dropped below $5 \mathrm{~g} / \mathrm{dL}$. As lactate levels only increase when tissue oxygen supply is not met for a longer period of time, increases in lactate levels are not observed in the case of short-term tissue hypoxia [40]. This temporal course significantly limits the usefulness of lactate measurements as a transfusion trigger. Furthermore, an increase in the arterial lactate level does not only occur if the oxygen demand of the tissues cannot be met anymore. There are several other reasons for a potential increase in the arterial lactate level, and therefore this parameter is also not highly specific, which makes interpretation rather difficult $[49,50]$.

Accordingly, no studies have been published so far, which could prove the effectiveness or safety of using lactate levels as a transfusion trigger.

\section{Near-Infrared Spectroscopy as a Transfusion Trigger}

Near-infrared spectroscopy (NIRS) is a method that allows noninvasive measurement of the summative oxygen saturation of a tissue. As its field of application has expanded considerably during recent years, it is not surprising that it has also been recommended as a transfusion trigger [51]. The rationale for its use as a transfusion trigger is that a severe decrease in regional oxygen saturation is associated with a deterioration in tissue oxygen supply. If a decrease in regional oxygen saturation occurs, it is often assumed that an intervention, typically the transfusion of RBCs in the context of anemia, restores tissue oxygen [52]. Several guidelines therefore also recommend NIRS as a possible method to individually determine the physiological transfusion threshold [53]. However, to date, no study has proven that the use of NIRS for this indication is safe and effective [54]. Smaller clinical studies have shown that RBC transfusions can increase NIRS values [55]. Whether this increase in regional oxygen saturation actually reflects an improvement in tissue oxygenation, or rather a decrease in oxygen depletion, remains unclear [55].
A further limitation makes interpretation of NIRS values under clinical conditions even more difficult: the location of the NIRS signal derivation is likely to play a decisive role in the significance of the values obtained. Depending on the tissue (muscle, liver, brain) for which the mixed oxygen saturation is derived, changes in tissue oxygen saturation vary between organs depending on the severity of anemia. This observation reflects the physiological principle of organ-specific anemia tolerance.

\section{Organ-Specific Anemia Tolerance}

All physiological transfusion triggers discussed above can theoretically indicate whether the body is sufficiently supplied with oxygen. In general, it can be assumed that this is particularly not the case anymore when the compensation mechanisms of acute anemia are no longer sufficient to ensure the myocardial oxygen demand [56].

During recent years, growing evidence suggests that not all organs are similarly affected by a decrease in oxygen supply at identical $\mathrm{Hb}$. Animal studies found that the maintenance metabolism of the kidneys is impaired at higher $\mathrm{Hb}$ levels than in other organs, especially the myocardium [22, 57]. However, it remains unknown whether this phenomenon is clinically relevant.

Should the phenomenon of organ-specific anemia tolerance actually play a role in clinical practice, this would once again call into question the concept of systemic transfusion triggers. A physiological transfusion trigger would then have to be found which reflects the impaired oxygen supply to the organ with the lowest anemia tolerance. To date, however, we are still far from knowing such a transfusion trigger, let alone whether there are interindividual differences in organ-specific anemia tolerance.

\section{Synopsis}

Despite intense research to identify an optimal transfusion trigger for patient-specific subgroups, the philosopher's stone has not yet been found on this subject. Theoretically, physiological transfusion triggers should be most suitable to determine the need for RBC transfusion. However, this concept has not yet been fully developed, and none of the physiological transfusion triggers used to date has been adequately investigated in large-scale clinical trials. In clinical routine, it is often assumed that RBCs are usually transfused after physiological transfusion triggers have been reached. However, a large European observational study has shown that transfusion is more likely to depend on $\mathrm{Hb}$ than on a physiological transfusion trigger [58]. 
Although Hb-based transfusion triggers seem to be the standard of care at the moment, it has to be pointed out that this approach suffers from several drawbacks. In the future, it would be desirable to have a set of physiological transfusion triggers that approach the physiological limits of acute anemia, without endangering single organs at risk. Currently, a combination of arterial lactate $/ \mathrm{SvO}_{2} /$ $\mathrm{SvcO}_{2}$ and NIRS seem to be most promising to avoid premature transfusion on the one side and ensure adequate tissue oxygen supply to organs at risk on the other side.

We are, therefore, still at the beginning of the process to identify the individual need for RBC transfusion. Larger clinical trials are needed to prove the outcome-benefit of such an approach.

\section{Disclosure Statement}

The authors have no conflicts of interest to declare.

\section{Funding Sources}

The authors received no funding for the work presented.

\section{Author Contributions}

All authors contributed equally to the preparation of the paper.

\section{References}

1 Desai N, Schofield N, Richards T. Perioperative Patient Blood Management to Improve Outcomes. Anesth Analg. 2018 Nov;127(5): 1211-20.

2 Shander A, Bracey AW Jr, Goodnough LT, Gross I, Hassan NE, Ozawa S, et al. Patient Blood Management as Standard of Care. Anesth Analg. 2016 Oct;123(4):1051-3.

3 Ott DA, Cooley DA. Cardiovascular surgery in Jehovah's Witnesses. Report of 542 operations without blood transfusion. JAMA. 1977 Sep;238(12):1256-8.

4 Hébert PC, Wells G, Blajchman MA, Marshall J, Martin C, Pagliarello G, et al. A multicenter, randomized, controlled clinical trial of transfusion requirements in critical care. Transfusion Requirements in Critical Care Investigators, Canadian Critical Care Trials Group. N Engl J Med. 1999 Feb;340(6):409-17.

5 Leahy MF, Hofmann A, Towler S, Trentino KM, Burrows SA, Swain SG, et al. Improved outcomes and reduced costs associated with a health-system-wide patient blood management program: a retrospective observational study in four major adult tertiary-care hospitals. Transfusion. 2017 Jun;57(6):1347-58.

6 Meybohm P, Herrmann E, Steinbicker AU, Wittmann M, Gruenewald M, Fischer D, et al.; PBM-study Collaborators. Patient Blood Management is Associated With a Substantial Reduction of Red Blood Cell Utilization and Safe for Patient's Outcome: A Prospective, Multicenter Cohort Study With a Noninferiority Design. Ann Surg. 2016 Aug;264(2): 203-11.

7 Boening A, Boedeker RH, Scheibelhut C, Rietzschel J, Roth P, Schönburg M. Anemia before coronary artery bypass surgery as additional risk factor increases the perioperative risk. Ann Thorac Surg. 2011 Sep;92(3):805-10.

8 Karkouti K, Grocott HP, Hall R, Jessen ME, Kruger C, Lerner AB, et al. Interrelationship of preoperative anemia, intraoperative anemia, and red blood cell transfusion as potentially modifiable risk factors for acute kidney injury in cardiac surgery: a historical multicentre cohort study. Can J Anaesth. 2015 Apr; 62(4):377-84.
9 Culleton BF, Manns BJ, Zhang J, Tonelli M, Klarenbach S, Hemmelgarn BR. Impact of anemia on hospitalization and mortality in older adults. Blood. 2006 May;107(10):38416.

10 Clevenger B, Richards T. Pre-operative anaemia. Anaesthesia. 2015;70 Suppl 1:20-8, e6-8.

11 Carson JL, Grossman BJ, Kleinman S, Tinmouth AT, Marques MB, Fung MK, et al.; Clinical Transfusion Medicine Committee of the AABB. Red blood cell transfusion: a clinical practice guideline from the AABB*. Ann Intern Med. 2012 Jul;157(1):49-58.

12 Carson JL, Stanworth SJ, Roubinian N, Fergusson DA, Triulzi D, Doree C, et al. Transfusion thresholds and other strategies for guiding allogeneic red blood cell transfusion. Cochrane Database Syst Rev. 2016 Oct; 10(5):CD002042.

13 Kozek-Langenecker SA, Ahmed AB, Afshari A, Albaladejo P, Aldecoa C, Barauskas G, et al. Management of severe perioperative bleeding: guidelines from the European Society of Anaesthesiology: First update 2016. Eur J Anaesthesiol. 2017 Jun;34(6):332-95.

14 Bundesärztekammer, editor. QuerschnittsLeitlinien zur Therapie mit Blutkomponenten und Plasmaderivaten: mit 19 Tabellen. 4., überarb. Köln: Dt. Ärzte-Verl; 2009.

15 Sergi G, Coin A, Sarti S, Perissinotto E, Peloso $\mathrm{M}$, Mulone S, et al. Resting VO2, maximal VO2 and metabolic equivalents in free-living healthy elderly women. Clin Nutr. 2010 Feb; 29(1):84-8.

16 Habler OP, Messmer KF. The physiology of oxygen transport. Transfus Sci. 1997 Sep; 18(3):425-35.

17 Cilley RE, Scharenberg AM, Bongiorno PF, Guire KE, Bartlett RH. Low oxygen delivery produced by anemia, hypoxia, and low cardiac output. J Surg Res. 1991 Nov;51(5):42533.

18 Torres Filho IP, Spiess BD, Pittman RN, Barbee RW, Ward KR. Experimental analysis of critical oxygen delivery. Am J Physiol Heart Circ Physiol. 2005 Mar;288(3):H1071-9.
19 Meier J, Pape A, Lauscher P, Zwissler B, Habler O. Hyperoxia in lethal methemoglobinemia: effects on oxygen transport, tissue oxygenation, and survival in pigs. Crit Care Med. 2005 Jul;33(7):1582-8.

20 Tobian AA, Ness PM, Noveck H, Carson JL. Time course and etiology of death in patients with severe anemia. Transfusion. 2009 Jul; 49(7):1395-9.

21 Crowe EP, DeSimone RA. Transfusion support and alternatives for Jehovah's Witness patients. Curr Opin Hematol. 2019 Nov; 26(6):473-9.

22 Lauscher P, Kertscho H, Schmidt O, Zimmermann R, Rosenberger P, Zacharowski K, et al. Determination of organ-specific anemia tolerance. Crit Care Med. 2013 Apr;41(4):1037-45.

23 Carson JL. Morbidity risk assessment in the surgically anemic patient. Am J Surg. 1995 Dec;170(6A Suppl):32S-6S.

24 Carson JL, Terrin ML, Noveck H, Sanders DW, Chaitman BR, Rhoads GG, et al.; FOCUS Investigators. Liberal or restrictive transfusion in high-risk patients after hip surgery. N Engl J Med. 2011 Dec;365(26):245362.

25 Hajjar LA, Vincent JL, Galas FR, Nakamura RE, Silva CM, Santos MH, et al. Transfusion requirements after cardiac surgery: the TRACS randomized controlled trial. JAMA. 2010 Oct;304(14):1559-67.

26 Mazer CD, Whitlock RP, Fergusson DA, Hall J, Belley-Cote E, Connolly K, et al.; TRICS Investigators and Perioperative Anesthesia Clinical Trials Group. Restrictive or Liberal Red-Cell Transfusion for Cardiac Surgery. N Engl J Med. 2017 Nov;377(22):2133-44.

27 Holst LB, Haase N, Wetterslev J, Wernerman J, Guttormsen AB, Karlsson S, et al.; TRISS Trial Group; Scandinavian Critical Care Trials Group. Lower versus higher hemoglobin threshold for transfusion in septic shock. N Engl J Med. 2014 Oct;371(15):1381-91.

28 Vincent JL, Baron JF, Reinhart K, Gattinoni L, Thijs L, Webb A, et al.; ABC (Anemia and Blood Transfusion in Critical Care) Investigators. Anemia and blood transfusion in critically ill patients. JAMA. 2002 Sep;288(12): 1499-507. 
29 Corwin HL, Gettinger A, Pearl RG, Fink MP, Levy MM, Abraham E, et al. The CRIT Study: anemia and blood transfusion in the critically ill-current clinical practice in the United States. Crit Care Med. 2004 Jan;32(1):39-52.

30 Trentino KM, Farmer SL, Leahy MF, Sanfilippo FM, Isbister JP, Mayberry R, et al. Systematic reviews and meta-analyses comparing mortality in restrictive and liberal haemoglobin thresholds for red cell transfusion: an overview of systematic reviews. BMC Med. 2020 Jun;18(1):154.

31 Lee PC, Kini AS, Ahsan C, Fisher E, Sharma SK. Anemia is an independent predictor of mortality after percutaneous coronary intervention. J Am Coll Cardiol. 2004 Aug;44(3): 541-6.

32 Habler O, Messmer K. Hyperoxaemia in extreme haemodilution. Br J Anaesth. 1998 Dec; 81 Suppl 1:79-82.

33 van Beest PA, Hofstra JJ, Schultz MJ, Boerma EC, Spronk PE, Kuiper MA. The incidence of low venous oxygen saturation on admission to the intensive care unit: a multi-center observational study in The Netherlands. Crit Care. 2008;12(2):R33

34 Lauscher P, Mirakaj V, Koenig K, Meier J. Why hyperoxia matters during acute anemia Minerva Anestesiol. 2013 Jun;79(6):643-51.

35 Napolitano LM, Corwin HL. Efficacy of red blood cell transfusion in the critically ill. Crit Care Clin. 2004 Apr;20(2):255-68.

36 Zimmerman R, Tsai AG, Salazar Vázquez BY, Cabrales P, Hofmann A, Meier J, et al. Posttransfusion Increase of Hematocrit per se Does Not Improve Circulatory Oxygen Delivery due to Increased Blood Viscosity. Anesth Analg. 2017 May;124(5):1547-54.

37 Piety NZ, Reinhart WH, Stutz J, Shevkoplyas SS. Optimal hematocrit in an artificial microvascular network. Transfusion. 2017 Sep; 57(9):2257-66.

38 Smit B, Smulders YM, van der Wouden JC, Oudemans-van Straaten HM, Spoelstra-de Man AM. Hemodynamic effects of acute hyperoxia: systematic review and meta-analysis. Crit Care. 2018 Feb;22(1):45.

39 Zhu Y, Park TS, Gidday JM. Mechanisms of hyperoxia-induced reductions in retinal blood flow in newborn pig. Exp Eye Res. 1998 Sep;67(3):357-69.
40 Pappachan LG, Williams A, Sebastian T, Korula $G$, Singh $G$. Changes in central venous oxygen saturation, lactates, and ST segment changes in a V lead ECG with changes in hemoglobin in neurosurgical patients undergoing craniotomy and tumor excision: A prospective observational study. J Anaesthesiol Clin Pharmacol. 2019 Jan-Mar;35(1):99-105.

41 Szekely P. Electrocardiographic findings in anaemia. Br Heart J. 1940 Jan;2(1):1-8.

42 Kocsi S, Demeter G, Érces D, Kaszaki J, Molnár Z. Central venous-to-arterial CO2-gap may increase in severe isovolemic anemia. PLoS One. 2014 Aug;9(8):e105148.

43 Adamczyk S, Robin E, Barreau O, Fleyfel M, Tavernier B, Lebuffe G, et al. Apport de la saturation veineuse centrale en oxygène dans la décision transfusionnelle postopératoire. Ann Fr Anesth Reanim. 2009 Jun;28(6):52230 .

44 Surve RM, Muthuchellappan R, Rao GS, Philip M. The effect of blood transfusion on central venous oxygen saturation in critically ill patients admitted to a neurointensive care unit. Transfus Med. 2016 Oct;26(5):343-8.

45 Vallet B, Adamczyk S, Barreau O, Lebuffe G. Physiologic transfusion triggers. Best Pract Res Clin Anaesthesiol. 2007 Jun;21(2):17381.

46 Tran A, Matar M, Steyerberg EW, Lampron J, Taljaard M, Vaillancourt C. Early identification of patients requiring massive transfusion, embolization, or hemostatic surgery for traumatic hemorrhage: a systematic review protocol. Syst Rev. 2017 Apr;6(1):80.

47 Meier J, Kemming GI, Kisch-Wedel H, Wölkhammer S, Habler OP. Hyperoxic ventilation reduces 6-hour mortality at the critical hemoglobin concentration. Anesthesiology. 2004 Jan;100(1):70-6.

48 Weiskopf RB, Viele MK, Feiner J, Kelley S, Lieberman J, Noorani M, et al. Human cardiovascular and metabolic response to acute, severe isovolemic anemia. JAMA. 1998 Jan; 279(3):217-21.

49 Suetrong B, Walley KR. Lactic Acidosis in Sepsis: It's Not All Anaerobic: Implications for Diagnosis and Management. Chest. 2016 Jan;149(1):252-61.

50 Seheult J, Fitzpatrick G, Boran G. Lactic acidosis: an update. Clin Chem Lab Med. 2017 Mar;55(3):322-33.
51 Orlov D, O’Farrell R, McCluskey SA, Carroll J, Poonawala H, Hozhabri S, et al. The clinical utility of an index of global oxygenation for guiding red blood cell transfusion in cardiac surgery. Transfusion. 2009 Apr;49(4):682-8.

52 Torella F, Haynes SL, Kirwan CC, Bhatt AN McCollum CN. Acute normovolemic hemodilution and intraoperative cell salvage in aortic surgery. J Vasc Surg. 2002 Jul;36(1):31-4.

53 Torella F, Haynes SL, McCollum CN. Cerebral and peripheral oxygen saturation during red cell transfusion. J Surg Res. 2003 Mar; 110(1):217-21.

54 Vretzakis G, Georgopoulou S, Stamoulis K, Tassoudis V, Mikroulis D, Giannoukas A, et al. Monitoring of brain oxygen saturation (INVOS) in a protocol to direct blood transfusions during cardiac surgery: a prospective randomized clinical trial. J Cardiothorac Surg. 2013 Jun;8(1):145.

55 Serraino GF, Murphy GJ. Effects of cerebral near-infrared spectroscopy on the outcome of patients undergoing cardiac surgery: a systematic review of randomised trials. BMJ Open. 2017 Sep;7(9):e016613.

56 van Bommel J, Siegemund M, Henny CP, Ince C. Heart, kidney, and intestine have different tolerances for anemia. Transl Res. 2008 Feb; 151(2):110-7.

57 Krömker M, Lauscher P, Kertscho H, Zacharowski K, Rosenberger P, Meier J. Anemia tolerance during normo-, hypo-, and hypervolemia. Transfusion. 2017 Mar;57(3):613-21.

58 Meier J, Filipescu D, Kozek-Langenecker S, Llau Pitarch J, Mallett S, Martus P, et al.; ETPOS collaborators. Intraoperative transfusion practices in Europe. Br J Anaesth. 2016 Feb;116(2):255-61.

59 Villanueva C, Colomo A, Bosch A, Concepción M, Hernandez-Gea V, Aracil C, et al. Transfusion strategies for acute upper gastrointestinal bleeding. N Engl J Med. 2013 Jan; 368(1):11-21.

60 Bergamin FS, Almeida JP, Landoni G, Galas FR, Fukushima JT, Fominskiy E, et al. Liberal Versus Restrictive Transfusion Strategy in Critically Ill Oncologic Patients: The Transfusion Requirements in Critically Ill Oncologic Patients Randomized Controlled Trial. Crit Care Med. 2017 May;45(5):766-73. 